\title{
Secondary Students' Involvement in Their IEP Meetings: Administrators' Perceptions
}

\author{
JAMES E. MARTIN \\ BARBARA A. GREENE \\ BRIAN J. BORLAND
}

\begin{abstract}
Secondary administrators in one southwestern state answered a 10-question web-based survey about student preparation for and involvement in their IEP meetings. Almost half of the 456 building-level special education administrative contacts who received our e-mail request completed the survey. Administrators reported that their schools teach students about their disability, invite them to their IEP meetings, encourage their participation at IEP meetings, and solicit student opinions during the meetings. Few administrators expected students to lead their own IEP meeting. Responses differed by administrative role. Principals answered questions differently than special education directors and special education teachers working part-time as administrators. The administrators' perceptions of student involvement differed from the results of direct observations of secondary IEP meetings.
\end{abstract}

The 1990 Individuals with Disabilities Education Act (IDEA) added three transition reforms to increase student involvement in IEP meetings as a means to improve postschool outcomes (Johnson, Stodden, Emanuel, Luecking, \& Mack, 2002; Storms, O'Leary, \& Williams, 2000). First, students 14 years old and older must be invited to their IEP meetings. Second, IEP meeting discussions must reflect student interests and preferences. Third, postschool goals and aspirations must direct the development of a plan of study and needed transition services. These reforms should facilitate active student engagement in the IEP process, and provide opportunities to increase student selfdetermination skills (Field, Martin, Miller, Ward, \& Wehmeyer, 1998; Martin, Huber Marshall, \& DePry, 2001; Test et al., 2004).

Unfortunately, implementation of IDEA's transition reforms has been slow, with most states failing to achieve minimal compliance with the transition requirements (Hasazi, Furney, \& DeStefano, 1999). The National Council on Disability (2000) reported " $88 \%$ or 44 states failed to ensure compliance with transition requirements" (p. 89). Specifically, Williams and O'Leary (2001) found that many schools did not invite students to their own IEP meetings. The U.S. Dept. of Education's Office of Special Education Program Expert Strategy 
Panel Report indicated that today's secondary schools provide too few opportunities for students to learn and practice IEP leadership skills prior to their IEP meeting (U.S. Department of Education, 2001).

In a qualitative study of secondary-aged students with disabilities, their parents, and teachers, Lehmann, Bassett, and Sands (1999) found that students do not engage in planning for their future without a structured process that expects them to become involved. Morningstar, Turnbull, and Turnbull (1995) found in their qualitative study that many students who received an invitation to their IEP meeting opt not to attend because they view the meetings as meaningless and not relevant to their future. In contrast, the students who did attend their IEP meetings and actively participated saw value to becoming engaged in the planning process. Zhang, Katsiyannis, and Zhang (2002) reported that most special education teachers do not provide students opportunities to develop their course schedules and postschool plans.

Lovitt, Cushing, and Stump (1994) discovered that when students attended their IEP meetings, they simply sat, listened, and seldom participated. Powers, Turner, Matuszewski, Wilson, and Loesch (1999) reported that most students wanted to participate and become actively involved in their IEP transition planning process, but ended up passively responding because they felt unwelcome and not respected at their IEP meetings. More recently, Martin et al. (2004) directly observed 109 secondary IEP meetings. They found that students talked $3 \%$ of the time compared to $51 \%$ for special education teachers, $15 \%$ for family members, $9 \%$ for administrators, and $2 \%$ of the intervals when no conversation occurred. Martin, Huber Marshall, and Sale (2004) studied almost 400 IEP meetings over a three-year period. Compared to special educators, general educators, administrators, parents, and support staff, students reported significantly lower responses in knowing the reasons for their IEP meeting, what to do at their meetings, feeling comfortable saying what they thought, talking about strengths and needs, understanding what was said, and feeling good about the meeting. Moreover, parents and special educators talked more about student interests than students themselves did.

Despite these rather dismal outcomes, numerous studies report that students can be taught to actively participate in their own IEP meetings. For example, Sweeney (1997) found that students who received instruction in how to participate at their IEP meetings compared to those who did not receive such instruction felt more in charge of their meeting, felt more confident that their IEP goals would be attained, shared more of their dreams for life after high school, and attended more of their meetings. Similarly, Allen, Smith, Test, Flowers, and Wood (2001), Mason, McGahee-Kovac, Johnson, and Stillerman (2002), Snyder (2002), Snyder and Shapiro (1997), Van Reusen and Bos (1994), and Zhang (2001) all have found that when taught IEP participation skills, students became engaged during the meetings, actively participated, and some even led their own IEP meetings. 
IDEA considers student involvement in the IEP process central to facilitating successful student-centered transition. Data suggest that students can learn the skills to actively participate in their IEP meetings and students will do so when they have the opportunity and are expected to play a major role at their meetings. Martin and Huber Marshall (1995), Field et al. (1998), and Sands, Spencer, Gliner, and Swaim (1999) believe that schools must first provide overt opportunities for students to learn the skills to actively become involved at their IEP meetings, and then schools must expect students to play a major role at their IEP meetings. Similarly, O'Hair, McLaughlin, and Reitzug (2000) believe that school administrators need to provide opportunities for students to become engaged in planning their own education.

Unfortunately, little to no statewide research exists about what schools do to prepare students for their IEP meetings and what administrators believe about student preparation and involvement in their IEP meetings. Thus, we conducted this study to determine secondary building-level administrators' perceptions of what their schools do to prepare and involve students in their IEP meetings.

\section{METHOD}

\section{Respondents}

Using a special education administrative contact list provided by the department of education in one southwestern state, we telephoned 612 public middle, junior high, and high schools to obtain the e-mail addresses of their building-level special education administrator. If a district did not have a separate middle or junior high, we asked for the special education administrative contact person for grades $6-8$ in their K-8 program. From these 612 schools, we obtained the e-mail addresses of 534 special education administrative contacts. Of these, 456 received our e-mail request to participate in this survey. The remaining 78 email messages came back as undeliverable because of an address error or the receiving system blocked receipt of our e-mail.

Of the 456 building-level special education administrative contacts who received our e-mail to participate in this study, $218(48 \%)$ responded to the survey. This included 132 principals, 63 special education directors, and 20 special education teachers who also worked as building-level administrators responded. Three respondents did not identify their role; their results were not included in the analyses.

\section{Instrumentation}

An e-mail message sent to all administrative contacts statewide explained the study and provided a hyperlink to take the participants to the survey website. 
Upon arrival at the website, participants could either choose to read more about the study or proceed directly to the survey. The first section of the survey asked participants to identify their major role from three possible choices: principal, special education director, or special education teacher/administrator. The second part consisted of 10 survey questions designed to determine how administrators viewed student preparation for and the extent of student involvement at their IEP meetings (see Table 1). Eight questions asked the respondents to choose from the following responses: always, most of the time, sometimes, or never. Two questions asked them to choose from very involved, moderately involved, somewhat involved, or not involved. We converted the responses using a $1-4$ scale, with 1 representing never or not involved and 4 representing always or very involved.

After submitting the survey, participants received a confirmation notice, and the data went directly into a database located on our campus server. One week after sending the initial e-mail, we sent a second message to those who had not

\section{Table 1}

\section{Survey Questions}

1. Are secondary students with mild to moderate disabilities invited to their IEP meetings?

_ Always _ Most of the time _ Sometimes _ Never

2. How often do the secondary students with mild to moderate disabilities attend their IEP meetings?

- Always _ Most of the time _ Sometimes _ Never

3. Are the IEP team members taught to facilitate student involvement in their IEP meetings?

- Always _- Most of the time _ Sometimes _ Never

4. On average, how involved are secondary students in their IEP meetings?

_ Very involved _ Moderately _ Somewhat _ Not involved

5. Are the secondary students asked for their opinion at the IEP meeting?

- Always _ Most of the time _ Sometimes _ Never

6. On average, how involved are parents in their child's secondary IEP meeting?

_ Very involved _ Moderately _ Somewhat _ Not involved

7. Are the secondary students encouraged to participate in their IEP meeting? - Always _ Most of the time _ Sometimes _ Never

8. Are the secondary students expected to direct their IEP meeting? - Always _ Most of the time _ Sometimes _ Never

9. Do you or your IEP team members actively involve secondary students in making decisions during their IEP meeting?

- Always _ Most of the time _ Sometimes _ Never

10. Do you or your team members educate secondary students with mild to moderate disabilities about their disability?

- Always _ Most of the time__ Sometimes_ _ Never


completed the survey. A week later a third e-mail was sent to those who still had not responded. After three more weeks, the non-responders received a fourth and final e-mail request to participate in the survey.

\section{RESULTS}

Table 2 depicts how building-level administrative contacts answered each question in the survey. As illustrated, participants reported that their schools encouraged students to participate at their IEP meetings, yet they also reported

Table 2

Means, Standard Deviations (SD), and Percent Response Results by Role for Each Question

\begin{tabular}{|c|c|c|c|c|c|c|c|c|}
\hline \multirow[b]{2}{*}{ Survey Question } & \multicolumn{2}{|c|}{ Principal } & \multicolumn{2}{|c|}{$\begin{array}{c}\text { SPED } \\
\text { Director } \\
\end{array}$} & \multicolumn{2}{|c|}{$\begin{array}{l}\text { Teacher/ } \\
\text { Admins }\end{array}$} & \multicolumn{2}{|c|}{ ANOVA } \\
\hline & $M$ & $\mathrm{SD}$ & $\mathrm{M}$ & $\mathrm{SD}$ & $\mathrm{M}$ & $\mathrm{SD}$ & $\mathrm{F}(\mathrm{df}, \mathrm{df})$ & $\eta^{2}$ \\
\hline $\begin{array}{l}\text { 1. Are students invited to their } \\
\text { IEP meeting?* }\end{array}$ & $3.3 \mathrm{a}$ & .83 & $3.8 \mathrm{~b}$ & .50 & $3.7 \mathrm{~b}$ & .57 & $(3,214)$ & .086 \\
\hline $\begin{array}{l}\text { 2. How often do students attend } \\
\text { their IEP meetings? }\end{array}$ & 2.5 & .69 & 2.7 & .63 & 2.5 & .76 & $(3,214)$ & .015 \\
\hline $\begin{array}{l}\text { 3. Does the IEP team know how } \\
\text { to facilitate student involvement } \\
\text { in their IEP meetings?* }\end{array}$ & $2.8 \mathrm{a}$ & .99 & $3.0 \mathrm{a}$ & .83 & $2.2 \mathrm{~b}$ & 1.0 & $(3,214)$ & .047 \\
\hline $\begin{array}{l}\text { 4. How involved are secondary } \\
\text { students in their IEP meetings? }\end{array}$ & 2.5 & .78 & 2.6 & .75 & 2.3 & .64 & $(3,214)$ & .017 \\
\hline $\begin{array}{l}\text { 5. Are students asked for their } \\
\text { opinion at the IEP meeting? }\end{array}$ & $3.1 \mathrm{a}$ & .83 & $3.4 \mathrm{~b}$ & .99 & $3.2 \mathrm{ab}$ & .95 & $(3,214)$ & .024 \\
\hline $\begin{array}{l}\text { 6. How involved are parents in } \\
\text { their child's secondary IEP } \\
\text { meeting?* }\end{array}$ & $3.3 \mathrm{a}$ & .66 & $3.2 \mathrm{a}$ & .67 & $2.9 \mathrm{~b}$ & .59 & $(3,214)$ & .043 \\
\hline $\begin{array}{l}\text { 7. Are students encouraged } \\
\text { to participate in their IEP } \\
\text { meeting?* }\end{array}$ & $3.2 \mathrm{a}$ & .83 & $3.7 \mathrm{~b}$ & .53 & $3.4 \mathrm{~b}$ & .59 & $(3,214)$ & .081 \\
\hline $\begin{array}{l}\text { 8. Are students expected to } \\
\text { direct their IEP meeting? }\end{array}$ & 1.2 & .44 & 1.3 & .45 & 1.3 & .57 & $(3,214)$ & .016 \\
\hline $\begin{array}{l}\text { 9. Do you or your IEP team } \\
\text { members actively involve } \\
\text { students in making decisions } \\
\text { during their IEP meeting?* }\end{array}$ & $2.8 \mathrm{a}$ & .82 & $3.2 \mathrm{~b}$ & .69 & $3.1 \mathrm{ab}$ & .83 & $(3,214)$ & .046 \\
\hline $\begin{array}{l}\text { 10. Do you or your team members } \\
\text { educate students about their } \\
\text { disability? }\end{array}$ & 3.1 & .83 & 3.2 & .85 & 3.2 & .85 & $(3,214)$ & .007 \\
\hline
\end{tabular}

Note. Means sharing common subscripts for each question are not significantly different. ${ }^{*} p<.05 ; \eta^{2}=$ effect size. 
that actual student involvement levels lag behind efforts to encourage participation. Administrators did not expect students to direct their meetings. Finally, administrators believed that parents were more involved in IEP meetings than students.

\section{Analysis of Mean Differences by Role}

A multivariate analysis of variance (MANOVA) was conducted to determine the impact of the administrative position (principal, special education director, and special education teacher/administrator) on the mean responses of the 10 survey questions. Based on their educational role, principals, special education directors, and special education teachers working part time as administrators answered the survey questions differently (Wilks's $\Lambda=.77, F(30,602)=1.86$, $p<.01, \eta^{2}=.08$ ).

Analyses of variances (ANOVA) on each question were conducted as followup tests to the MANOVA. As depicted in Table 3, Questions 1, 3, 6, 7, and 9 yielded significant ANOVA results. Post hoc analyses were conducted for each item using pairwise comparisons to identify the respondent role that affected survey responses most strongly (see Table 2). Each pairwise comparison was tested at the .05 level using the conservative Scheffe statistic.

As seen from Table 2, principals differed significantly from the other respondents on whether students were invited to IEP meetings and were encouraged to participate (Questions 1 \& 7). Specifically, special education directors believed significantly more so than principals that students' opinions are solicited at the IEP meetings, and that team members involve students in decision-making (Questions 5 \& 9). Special education teachers serving as administrators indicated that the IEP team knows how to facilitate student involvement in the IEP meeting significantly less than the degree indicated by principals and special education directors (Question 3). Further, these same teacher administrators believed that parents were involved in the IEP meetings to a lesser degree than principals and special education directors (Question 6).

\section{Response Summary by Question}

In the following, we will look at the findings for each individual question.

Are students invited to their IEP meetings and how often do they attend? Almost all special education directors and special education teacher/administrators reported that students with mild to moderate disabilities were invited to their IEP meetings. Principals, on the other hand, believed that students were invited less often than directors and special education teacher/administrators. All respondents reported that secondary students attended their IEP meeting some to most of the time.

Does the IEP team know how to facilitate student involvement in their IEP meeting? No consistent pattern emerged on how the IEP team learned to involve 
Table 3

ANOVA Results for Each Survey Question

\begin{tabular}{lcccc}
\hline Question & F (3, 214) & Significance & Eta Squared & Observed Power \\
\hline 1 & 6.7 & $<.01$ & .09 & .97 \\
3 & 3.54 & $<.01$ & .05 & .78 \\
6 & 3.19 & $<.01$ & .04 & .73 \\
7 & 6.27 & $<.01$ & .08 & .96 \\
9 & 3.44 & $<.01$ & .05 & .77 \\
\hline
\end{tabular}

students in their IEP meetings. Notably, almost $60 \%$ of the respondents reported that IEP team members received little to no training in how to facilitate student involvement. The special education teachers who worked as part-time administrators reported that the teams were less prepared to facilitate student involvement than did principals and special education directors.

How involved are students and are they asked for their opinions at their IEP meetings? The administrators reported that students were somewhat to moderately involved in their IEP meetings. Interestingly, $10 \%$ of the principals and $8 \%$ of the special education directors indicated that students were very involved. In contrast, no special education teacher/administrator reported that students were very involved. Over $75 \%$ of the administrators reported that team members almost always asked students for their opinions. However, principals and special education directors differed on the extent they believed this happened. Specifically, over $60 \%$ of special education directors, in contrast to $38 \%$ of the principals, reported that students were asked their opinion. The special education teacher/administrators' responses fell between the opinions of the directors and principals.

How involved are parents in the IEP meetings, are students encouraged to participate in their IEP meetings, and are students expected to direct their own IEP meetings? All administrators agreed that parents of children with mild to moderate disabilities were somewhat to very involved in their IEP meetings. For example, almost $40 \%$ of the principals and special education directors reported that parents were very involved, compared to $10 \%$ of the special education teachers. Over $95 \%$ of the special education directors and special education teacher/administrators reported that students were always encouraged to participate in their IEP meetings, whereas principals believed students were only sometimes encouraged to participate. Only a few respondents reported that secondary students with mild to moderate disabilities were expected to lead their IEP meeting.

Does the IEP team involve students in decision-making, and is the student taught about their disability? Almost $85 \%$ of the special education directors and $70 \%$ of special education teacher/administrators indicated that IEP teams involved students in making decisions. Once again, principals responded with the lowest 
score (mean $=2.8$ ). About $75 \%$ of the administrators believed that their schools teach students about their disability.

\section{Reliability}

The reliability coefficient analysis for the 10-survey questions yielded a .82 coefficient alpha. This suggests that the survey had high internal consistency, and therefore satisfactory reliability.

\section{Discussion}

The administrators who responded to the survey described here believed that their schools invited and encouraged students to become involved in their own IEP meetings. Principals believed students were invited less often than directors and special education teacher/administrators. All believed that students attended their IEP meeting some to most of the time. In contrast to the special education teacher/administrators, principals and directors indicated that IEP team members received some training on how to facilitate student involvement in the IEP meeting. Many administrators wanted students to actively participate in their meetings, but few expected students to lead or direct their own meetings. Administrators typically believed team members solicited student opinions during the meeting and that students become involved in decision-making. Special education teacher/administrators indicated parents were significantly less involved than their administrative counterparts.

Even though the respondents indicated that their schools invited students to their IEP meetings almost all the time, they believed students only attended some to most of the time. Why the discrepancy between the invitation rate and actual meeting attendance? Perhaps, the school culture has not evolved to the point where students are expected to attend their meetings. As an indication of this culture, even when students do attend their meetings, administrators thought that they were only somewhat involved in their meetings. If the school culture valued active student participation at their IEP meetings, students would most likely attend at greater rates, and their level of involvement would increase as noted by several researchers (e.g., Field, et al., 1998; Sands et al., 1999). The relatively low level of perceived student engagement in the IEP process found in this study clearly does not meet the intent of IDEA's transition reforms.

\section{Different Perceptions of Student Involvement}

Martin, Van Dycke, et al. (2004) directly observed 109 secondary IEP meetings in the same southwestern state where the present study was conducted. Their observations, which occurred during the same time span as this survey, indicated that students only talked $3 \%$ of intervals. In contrast, the respondents reported that their students are involved somewhat to moderately 
in their IEP meetings. The administrators in this study reported a higher level of student involvement than actually observed. Clearly, administrators believe students are involved to a greater extent than observations suggest.

\section{Implications for Practice}

Facilitating student leadership: Administrators' need for information. Numerous studies have demonstrated that secondary students can learn the skills necessary to actively participate and lead their IEP meetings. Yet, the respondents in this study indicated that their schools do not expect students to direct their own IEP meetings. O'Hair et al. (2000) tell administrators that they need to provide opportunities for students to become engaged in planning their own education. Leadership, or at least active participation in the IEP process, provides an excellent opportunity for students with disabilities to engage in their educational and postschool planning. Administrators must learn the benefits of students learning to lead and actively participate in their own IEP meetings, and their role in facilitating this learning outcome.

Dialogue between teachers and administrators. In comparison to the special education teacher/administrators, principals often under- or over-reported scores on the survey questions. A gap in understanding seems to exist between the special education teachers who work as part-time administrators and their full-time administrative counterparts, especially the principal. Compared to directors and principals, special education teacher/administrators considered the IEP team to be less prepared to facilitate student involvement. Special education teacher/administrators also reported that no students were very involved in their IEP meeting, and that only a few parents were very involved. Opportunities to discuss the IEP process must be scheduled so that special education can dialogue with their administrators about student involvement in their IEP meetings and transition practices that occur in their buildings. Likewise, administrators must take time to discuss these issues with their special education teachers.

Parental role and student involvement. Martin, Huber Marshall, et al. (2004) found that when students attended their IEP meetings, parents reported feeling that the meetings were more significant than when students did not attend the meeting. Perhaps as students become more involved in their IEP meeting parental engagement will increase, but parental interaction may decrease from the moderate to high levels administrators reported in this study. Parents need to learn about the benefits of student active participation in their own transition IEP meeting and their role in facilitating their child's leadership of the process.

\section{Limitations of this Study}

We designed this survey with a maximum of 10 questions so that busy building administrators could quickly respond. The brevity came at a cost. We do not know, for instance, how many IEP meetings the administrator had 
actually attended the past year, nor do we know the students the administrators had in mind as they answered the questions. Further, we do not know if the responses vary by rural, suburban, and urban schools, and if the responses varied by the administrators' background.

Initially we did not expect special education teachers to become involved in this study. However, we found that in many schools, especially rural ones, special education teachers also serve as the special education director or the assistant director. The teacher/administrators' responses made an excellent contribution to this study. Because they spend time each day teaching students, their comments reflect a hands-on, local perspective.

\section{Suggestions for Future Research}

Surprisingly, over $70 \%$ of the respondents indicated that students are typically taught about their disability. This finding raises many issues. For example, how are students taught about their disabilities? Where does this occur, and who teaches them? To what extent do students learn about their disabilities? What curriculum is used? Is this a functional definition or are they simply given the label for their disability? Do they learn what accommodations and modifications work best for them? What do students think and feel when they learn about their disability? Future research needs to address these questions. Future research also needs to examine why administrators overreport actual student involvement data.

The survey results suggest that building-level administrators believe that students are involved in their IEP process. What does this mean? Do students talk the majority of the time during the meeting, or do they simply respond when asked? Or, do administrators believe that attendance at the meeting equals participation?

Principals' opinions of the IEP processes differ significantly from that expressed by special education directors and special education teacher/administrators. Principals reported that students are less involved than did directors and teacher/administrators. Principals also believed parents are more involved in the IEP process than did special education directors and teacher/administrators. Whose perception represents reality the best?

Finally, the administrative responses from this survey differ remarkably from the national studies that report states being out of compliance with IDEA's transition reforms. Is it that this one southwestern state is doing better than others, or is it a matter of differing perceptions?

\section{ConClusion}

Sands et al. (1999) found that students needed the opportunity and expectation to set, express, and act on their own goals during the transition 
planning process to become meaningfully involved. According to respondents from this southwestern state, students had the opportunity to attend their IEP meetings and express their opinions. Yet, respondents reported that only a few students became very involved in their IEP meetings. The fact that most respondents in this survey did not expect students to actively lead their own meeting may explain why, in fact, so few students actively participated.

\section{REFERENCES}

Allen, S. K., Smith, A. C., Test, D. W., Flowers, C., \&. Wood, W. M. (2001). The effects of "SelfDirected IEP" on student participation in IEP meetings. Career Development for Exceptional Individuals, 24, 107-120.

Field, S., Martin, J., Miller, R., Ward, M., \& Wehmeyer, M. (1998). Self-determination for persons with disabilities: A position statement of the division on career development and transition. Career Development for Exceptional Individuals, 21, 113-128.

Hasazi, S. I., Furney, K. S., \& DeStefano, L. (1999). Implementing the IDEA transition mandates. Exceptional Children, 65, 555-566.

Johnson, D. R., Stodden, R. A., Emanuel, E. A., Luecking, R., \& Mack, M. (2002). Current challenges facing the future of secondary education and transition services. What the research tells us. Exceptional Children, 68, 519-531.

Lehmann, J. P., Bassett, D. S., \& Sands, D. J. (1999). Students' participation in transition related actions: A qualitative study. Remedial and Special Education, 20, 160-169.

Lovitt, T. C., Cushing, S. S., \& Stump, C. S. (1994). High school students rate their IEPs: Low opinion and lack of ownership. Intervention in School and Clinic, 30, 34-38.

Martin, J. E., \& Marshall, L. H. (1995). ChoiceMaker: A comprehensive self-determination transition program. Intervention in School and Clinic, 30, $147-156$.

Martin, J. E., Huber Marshall, L., \& DePry, R. L. (2001). Participatory decision-making: Innovative practices that increase student self-determination. In $\mathrm{R}$. W. Flexer, T. J. Simmons, P. Luft, \& R. M. Baer (Eds.), Transition planning for secondary students with disabilities (pp. 304-332). Columbus, OH: Merrill Prentice Hall.

Martin, J. E., Huber Marshall, L., \& Sale, P. (2004). A 3-year study of middle, junior high, and high school IEP meetings. Exceptional Children, 70, 285-297.

Martin, J. E., Van Dycke, J., Greene, B. A., Gardner, J. E., Christensen, R., \& Lovett, D. L. (2004). Direct observation and participant opinions of secondary IEP meetings. Manuscript submitted for publication.

Mason, C. Y., McGahee-Kovac, M., Johnson, L., \& Stillerman, S. (2002). Implementing student-led IEPs: Student participation and student and teacher reactions. Career Development for Exceptional Individuals, 25, 171-192.

Morningstar, M. E., Turnbull, A. P., \& Turnbull, H. R. (1995). What do students with disabilities tell us about the importance of family involvement in the transition from school to adult life? Exceptional Children, 62, 249-260.

National Council on Disability. (2000). Back to School on Civil Rights. Washington, DC: Author.

O’Hair, M. J., McLaughlin, H. J., \& Reitzug, U. C. (2000). Foundations of democratic education. Fort Worth, TX: Harcourt College Publishers.

Powers, L. E., Turner, A., Matuszewski, J., Wilson, R., \& Loesch, C. (1999). A qualitative analysis of student involvement in transition planning. The Journal for Vocational Sperial Needs Education, 21, 18-26.

Sands, D. J., Spencer, K. C., Gliner, J., \& Swaim, R. (1999). Structural equation modeling student involvement in transition-related actions: The path of least resistance. Focus on Autism $\hat{\mathcal{F}}^{2}$ Other Developmental Disabilities, 14, 17-27, 35. 
Snyder, E. P. (2002). Teaching students with combined behavioral disorders and mental retardation to lead their own IEP meetings. Behavioral Disorders, 27, 340-357.

Snyder, E. P., \& Shapiro, E. S. (1997). Teaching students with emotional/behavioral disorders the skills to participate in the development of their own IEPs. Behavioral Disorders, 22, 246-259.

Storms, J., O'Leary, E., \& Williams, J. (2000). The individuals with disabilities education act of 1997 transition requirements: A guide for states, districts, schools, universities and families. (Available from Publications Office, Institute on Community Integration, University of Minnesota, 109 Pattee Hall, 150 Pillsbury Drive, SE, Minneapolis, MN 55455).

Sweeney, M. A. (1997). The effects of self-determination training on student involvement in the IEP process (Doctoral dissertation, Florida State University, 1997). Dissertation Abstracts International, 58 (03), 821. (UMI No. 9725019)

Test, D. W., Mason, C., Hughes, C., Konrad, M., Neale, M., \& Wood, W. M. (2004). Student involvement in individualized education program meetings. Exceptional Children, 70, $391-412$.

U.S. Department of Education, Office of Special Education Programs. (2001). Students with disabilities' secondary education, transition, and employment (Expert Strategy Panel Report). Retrieved December 1, 2003, from http://www.ed.gov/offices/osers/osep. Washington, DC: Author.

Van Reusen, A. K., \& Bos, C. S. (1994). Facilitating student participation in individualized education programs through motivation strategy instruction. Exceptional Children, 60, $466-475$.

Williams, J. M., \& O'Leary, E. (2001). What we've learned and where we go from here. Career Development for Exceptional Individuals, 24, 51-71.

Zhang, D. (2001). The Effect of "Next S.T.E.P." instruction on the self-determination skills of high school students with learning disabilities. Career Development for Exceptional Individuals, 24, 121-132.

Zhang, D., Katsiyannis, A., \& Zhang, J. (2002). Teacher and parent practice on fostering selfdetermination of high school students with mild disabilities. Career Development for Exceptional Individuals, 25, 157-169.

\section{AUTHOR NOTES}

Funding provided by the U.S. Department of Education, Office of Special Education Programs field-initiated research (CFDA 84.324C) grant award number H324C020045 partially supported implementation of this study and preparation of this manuscript.

\section{AUTHOR INFORMATION}

James Martin, Ph.D., is the Zarrow Endowed Chair, Professor of Special Education, and Director of the Zarrow Center for Learning Enrichment; Barbara A. Greene, Ph.D., is the O'Brien Presidential Professor, Professor of Instructional Technology and Psychology, and Chair, Department of Educational Psychology; Brian Borland is a graduate student at the Zarrow Center for Learning Enrichment, all at the University of Oklahoma.

\section{CONTACT INFORMATION}

Correspondence concerning this article should be addressed to James $\mathrm{E}$. Martin, The University of Oklahoma, Zarrow Center for Learning Enrichment, 840 Asp Ave. room 111, Norman Oklahoma, 73019-4090. e-mail: jemartin@ou.edu. 